\title{
Impact of insurance and inflation on economic growth and food market security
}

\section{Mykhailo Arych ${ }^{1}$, Tetiana Didenko', Ekaterina Pozdniakova², Mariia Korniienko1, Yana Kripak ${ }^{1}$}

\author{
1 - National University of Food Technologies, Kyiv, Ukraine \\ 2 - Belarusian State Agrarian Technical University, Minsk, Belarus
}

\section{Keywords: \\ Insurance \\ Inflation \\ Security \\ Food \\ Export \\ Import \\ Gross}

\section{Article history:}

Received

21.10.2019

Received in

revised form

30.04.2020

Accepted

30.06.2020

Corresponding author:

Mykhailo Arych

E-mail:

mykhailo.arych@

nuft.edu.ua

\section{DOI:}

10.24263/2310-

1008-2020-8-1-

14

\section{Abstract}

Introduction. The objective of this research is to investigate the impact of insurance and inflation on economic growth and food market security. Altogether, the most crucial task of this paper is related to estimation the interconnection between consumer prices, total gross insurance premiums and gross domestic product, food exports and food imports.

Materials and methods. The research model was developed by reviewing the previous studies and applying the correlation-regression analysis for defining the impact of insurance and inflation on economic growth and food market security. Thus, it was calculated the coefficient of pair correlation or Pearson correlation coefficient (r) and coefficient of determination $\left(\mathrm{r}^{2}\right)$, Significance $\mathbf{F}$, as whole, $\mathbf{P}$-value for regression coefficient and one-factor regression equations that have a liner form.

Results and discussion. The research findings of this study indicate that by the level of relationship and by statistical significance of impact of insurance and inflation on economic growth and food market security all our 17 research countries were divided into four groups. Group 1 - strong uphill (downhill) linear relationship where coefficient $0.700 \leq \mathbf{r}<0.900(-0.900<\mathbf{r} \leq-0.700)$. For example, this type of interconnection describes the impact of inflation on gross domestic product in Turkey, Italy, Spain and Denmark; or impact of insurance on food export in Australia, Iceland, Netherlands, France, Turkey and Belgium. Group 2 - a moderate uphill (downhill) relationship where $0.500 \leq \mathbf{r}<0.700(-0.700<\mathbf{r} \leq-0.500)$. For instance, this type of interconnection indicates the impact of inflation on food export in France and Turkey; or impact of insurance on food import in France, Switzerland, United Kingdom, Netherlands and Spain. Group 3 - a weak uphill (downhill) linear relationship where $0.300 \leq \mathbf{r}<0.500$ $(-0.500<\mathbf{r} \leq-0.300)$. For example, this type of interconnection describes the impact of inflation on food import in Denmark, France, Finland, Turkey, Switzerland and Belgium; or impact of insurance on food import in Australia, Finland, Japan and Denmark. Group 4 - no linear relationship: $0.000 \leq \mathbf{r}<0.300(-0.300<\mathbf{r} \leq 0.000)$. It indicates the impact of insurance and inflation on economic growth and food market security in all other countries and cases except as described groups 1,2 , and 3 .

Conclusions. Our paper has provided new evidence of impact of insurance and inflation on economic growth and food market security which could help to increase regulation approaches for financial market and food market security in the world level. 


\section{Introduction}

The economic growth and food market security is one of the key points of the national development of countries. In addition, currently a lot of factors influence these indicators, and that's why it is important to understand the nature of its. In our research study we focus on the inflation and insurance as the factor variables and gross domestic product (GDP) and food export and import as target functions (dependent variables).

The critical literature review of foreign experience shows that insurance has significant effect on food market security. According to Isaboke et al. (2016) it was analyzed the impact of weather index based micro-insurance on food security status of smallholders. These study results show the positive effect of index insurance on food security [1]. In addition, Mârzaa et al. (2015) argued that insurance alone cannot provide food security [2]. Furthermore, based on the Agricultural Insurance Conference (2014) agricultural insurance should be seen as one component of the ACS and it is related to food security [3]. Altogether, the effect of agricultural insurance scheme on agricultural production in Ondo state (Nigeria) was studied by Akinrinola O.O. and Okunola A.M. (2014). The results show that there may be an increase in the level of investment of farms after participating in insurance [4].

In general, Kim Y., Pendell D.L. and Yu J. (2018) suggest that one of the key study points of the influence of insurance on food market security were focused on the effects of crop insurance on farm disinvestment and exit decisions [5]; besides, according to Zhao Y. and Preckel P. (2016) an empirical analysis of the effect of crop insurance on farmers' income [6]; the effects of subsidized crop insurance on crop choices [7]; risk management in the ACS with special attention to insurance $[8 ; 9]$.

It was also analyzed the literature review on the interconnection between insurance and economic growth. Outreville (2011) noted that influence of the insurance on the macroeconomic activity can be described from two viewpoints as follows: first, in providing indemnification; and, second, its role as an institutional investor [10]. In addition, according to Njegomir \& Stojić (2010), Stojaković \& Jeremić (2016) and others the positive impact of life insurance on economic growth can be based on the effects of financial stability, competitiveness of trade and commerce, increases liquidity [11-15]; the loss reduction [16]; increasing of new capital [10; 17]; risk management and financial management [18-20].

Furthermore, based on the research results of Nwani \& Omankhanlen (2019), Pradhan et al. (2017), Satrovic (2019) it was found that the life premium was positively insignificant to economic growth and the non-life premium - negatively, while the insurance investment - positively [15; 21; 22]. However, Pradhan et al. (2017) noted that in the long run, insurance have had a significant impact on the economic growth, and in the short term - the interrelationships differ by countries [22].

Studying the factors of food inflation Qayyum and Sultana (2018) analyzed the GDP, food exports, food imports, taxes and money supply as the independent determinants. As a result of this research it was recommended that special attention has to be paid on food exports and food imports along with excess money supply [23]. Also, according to Islam (2013), there is a positive correlation between domestic inflation and import [24]. In addition, Muktadir-Al-Mukit D., Shafiullah A.Z.M. and Ahmed R. (2013) noted that there is a a stable, positive and significant relationship between inflation and import [25]. Besides, significant research results about the analysis of relationship between import, export and inflation were obtained by Kiganda, Obange and Adhiambo (2017), Ahmed, Ghauri, Vveinhardt, Streimikiene (2018), which studied the cases of Kenya [26] and Pakistan [27]. Furthermore, in the worldwide level, food market security, food prices or food inflation was studied by Gazdar and Mallah (2013), Løvendal, Jakobsen and Jacque (2007), Huppé, Shaw, Dion, 
Voora (2013). It was presented their research results of a qualitative study of food security among rural and urban households to better understand the perceptions, behavior etc. [28]; the development of retail food prices, its causes, the potential impact thereof in terms of food security [29]; the assessment of Morocco's food security strategy and trade policy and important detailed analysis in the context of the current global economic situation [30].

Next significant part of our research describes the impact of inflation on economic growth. The critical literature review shows a lot of world recognized scientists has used different approaches and has obtained its own evidence base conclusions. Mukoka (2018) has argued that controlling the rise in the overall price level is necessary but not necessary for the Zimbabwean economy. This study based on the Dickie Fuller Test (ADF), cointegration analysis, Jacques-Behr test. The hypothesis underpinning this research is that inflation is negatively related to the economic surge [31].

Another significant result studying the influence of inflation on economic growth were obtained by Švigir and Miloš (2017). The group of scientists deals with the assessment of the impact of rising prices on the economy through an imperial analysis. It was analyzed the data collected cover more than 100 countries from 1960 to 1990. A system of regression equations was used to analyze the impact of inflation on economic recovery [32]. In addition, according by Ruzima and Veerachamy (2016) the theoretical and empirical studies of the effects of inflation on economic growth were examined. The results stated that there is no consensus on the relationship between inflation and economic growth in both theoretical and empirical studies [33].

Furthermore, Mishchenko et al. (2018) has studied the impact of inflation on economic growth and argued the main directions of increasing the effectiveness of central bank antiinflation policy. It was concluded that rising inflation significantly slows down economic growth [34]. Akinsola \& Odhiambo (2017) states that impact of inflation on economic recovery varies by country, and negatively correlated, most notably in advanced economies [35].

\section{Materials and methods}

\section{Materials}

The source of the statistical data for the research study was the information materials based on the World Bank Open Data (gross domestic product (GDP), inflation (consumer prices), food export, food import) [36] and OECD Insurance Statistics (total gross insurance premiums by countries) [37]

Studying the role and impact of the insurance and inflation on economic growth and food market security more than 100 articles and research papers were analyzed from the Google Scholar, ResearchGate, ScienceDirect, Academia.edu and other resources with various permutations of the following keywords: "food security", "market", "inflation", "insurance", "food export", "food import". The results of literature review show that more than forty research studies most directly associated with the influence of insurance and inflation on economic growth and food market security. This list of publications was the theoretical background for this research study. 


\section{Methods}

\section{Key research indicators}

The analysis of the impact of insurance and inflation on economic growth and food market security was performed based on the economic indicator as follows:

1) inflation, consumer prices (annual \%);

2) total gross insurance premiums (US Dollar, billions);

3) GDP - gross domestic product (US Dollar, billions);

4) food exports (\% of merchandise exports);

5) food imports (\% of merchandise imports).

In this list the indicators number 4 and 5 are indexes of food market security because they explain of merchandise export and imports structure. And these circumstances are very important for providing the food market security in every country.

These research indicators were collected and processed for the study period 1960-2018 for the following 17 countries: Australia, Belgium, Denmark, Finland, France, Germany, Iceland, Ireland, Italy, Japan, Netherlands, Norway, Portugal, Spain, Turkey, Switzerland and United Kingdom (UK).

\section{Correlation-regression analysis}

The study of the relationship and interconnection between the insurance, inflation, economic growth and food market security was performed based on the coefficient of pair correlation or Pearson correlation coefficient ( $r)$ and coefficient of determination $\left(\mathrm{r}^{2}\right)$.

The assessment of the impact of insurance and inflation on economic growth and food market security was conducted based on the correlation-regression analysis according to the available data. The regression equations are used in linear type (one-factor and multivariate regression equations). This economic-statistical analysis was conducted using the Microsoft Office software packages. For this analysis we determined three target research functions $\mathrm{Y}_{1}$, $\mathrm{Y}_{2}, \mathrm{Y}_{3}$; and two factor variables $\mathrm{X}_{1}$ and $\mathrm{X}_{2}$ (table 1).

Macroeconomic target functions and factors for the regression analysis

Table 1

\begin{tabular}{|c|l|l|}
\hline Marking & \multicolumn{1}{|c|}{ Explanation } & Unit of measure \\
\hline \multicolumn{3}{|c|}{ Target functions $\mathrm{Y}_{\mathrm{n}}\left(\mathrm{Y}_{1}, \mathrm{Y}_{2}, \mathrm{Y}_{3}\right)$} \\
\hline $\mathrm{Y}_{1}$ & GDP (Gross domestic product) & US Dollar, billions \\
\hline $\mathrm{Y}_{2}$ & EX (Food exports) & $\%$ of merchandise exports \\
\hline $\mathrm{Y}_{3}$ & IM (Food import) & $\%$ of merchandise import \\
\hline \multicolumn{2}{|l|}{ Factor variables $\mathrm{X}_{\mathrm{n}}\left(\mathrm{X}_{1}, \mathrm{X}_{2}\right)$} & annual \% \\
\hline $\mathrm{X}_{1}$ & INF (Inflation, consumer prices) & US Dollar, billions \\
\hline $\mathrm{X}_{2}$ & $\begin{array}{l}\text { INP (Total gross insurance } \\
\text { premiums) }\end{array}$ &
\end{tabular}

Source: Elaboration of authors.

According to the research procedure, for each correlation-regression dependence it is planned to calculate Pearson correlation coefficient $(\mathbf{r})$, determination coefficient $\left(\mathbf{r}^{2}\right)$, Significance $\mathbf{F}$ for regression equations as whole (Sign. F), P-value for $\mathrm{Y}_{0}$ and one-factor regression equations that have a liner form: 


$$
\text { Economics- }
$$

where $Y_{0}$ is the free coefficient; $a_{n}$, is correlation coefficient. In addition, based on the Significance $\mathbf{F}$ for regression (Sign. $\mathbf{F}$ ) and $\mathbf{P}$-value for $\mathbf{Y}_{0}$ we can describe the significance of each correlation-regression dependence. For example, when P-value is less than 5.0\% $(0.05)$ - the coefficient is statistically significant (reliability $=95 \%)$. In this case we can include this indicator in regression model. But when $\mathbf{P}$-value is greater than $5.0 \%(0.05)-$ the coefficient is statistically insignificant with a reliability of $95 \%$ - here it doesn't allow to include $\mathrm{Y}_{0}$ in regression equations [38]. In the same way we can characterize the values of Significance $\mathbf{F}$ for regression model.

\section{Results and discussion}

\section{Ranking of countries}

Based on the Pearson correlation coefficient (r) we have ranked all 17 countries in four groups by statistical significance of impact of insurance and inflation on economic growth and food market security. Thus, these groups are listed below:

Group 1, where between target functions $\mathrm{Y}_{\mathrm{n}}\left(\mathrm{Y}_{1}, \mathrm{Y}_{2}, \mathrm{Y}_{3}\right)$ and factor variables $\mathrm{X}_{\mathrm{n}}\left(\mathrm{X}_{1}\right.$, $\mathrm{X}_{2}$ ) there is a strong uphill (downhill) linear relationship because here we have $0.700 \leq \mathbf{r}<$ $0.900(-0.900<\mathbf{r} \leq-0.700)$. These calculations are presented in Table 2;

Group 2 - a moderate uphill (downhill) relationship (Table 3), where Pearson correlation coefficient $0.500 \leq \mathbf{r}<0.700(-0.700<\mathbf{r} \leq-0.500)$;

Group 3 - a weak uphill (downhill) linear relationship (Table 4), where correlation coefficient $0.300 \leq \mathbf{r}<0.500(-0.500<\mathbf{r} \leq-0.300)$;

Group 4 - no linear relationship: $0.000 \leq \mathbf{r}<0.300(-0.300<\mathbf{r} \leq 0.000)$. It is related to the all our countries and cases of relationships except as described in Tables 2, 3 and 4. Also, it is important to notice that there is not any cases of relationship between target functions and factor variables where we have a perfect uphill (downhill) linear relationship: $0.900 \leq \mathbf{r} \leq 1.000(-1.000 \leq \mathbf{r} \leq-0.900)$.

Our analysis starts with a presentation of correlation-regression statistics the estimates the impact of inflation and insurance on economic growth and food market security. Thus, Table 2 describes the list of top-countries where correlation coefficients show the a strong uphill (downhill) linear relationship between these economic indicators. In addition, based on the values of Pearson correlation coefficient (r) almost in every case we can see the downhill linear relationship, because $-0.900<\mathbf{r} \leq-0.700$. It shows the inversely proportional dependence between the inflation, insurance and economic growth and food market security. Here, we have only two exceptions of directly proportional relationship as follows: interconnection between inflation and food exports (\% of merchandise exports) in Denmark where $\mathbf{r}=0.707$; and between total gross insurance premiums and food import ( $\%$ of merchandise import): $\mathbf{r}=0.757$.

Looking at Table 3 figures, we can see a list of countries where the interconnection between insurance, inflation and economic growth and food market security has a moderate uphill (downhill) linear relationship because of where Pearson correlation coefficient 0.500 $\leq \mathbf{r}<0.700(-0.700<\mathbf{r} \leq-0.500)$. 
Table 2

List of countries where inflation $\left(\mathbf{X}_{1}\right)$ and insurance $\left(\mathbf{X}_{2}\right)$ have a strong uphill (downhill) linear relationship with economic growth $\left(\mathbf{Y}_{1}\right)$ and food market security $\left(\mathbf{Y}_{2}, \mathbf{Y}_{3}\right)$

\begin{tabular}{|c|c|c|c|c|c|}
\hline Country & $\mathbf{r}$ & $\mathbf{r}^{2}$ & $\begin{array}{c}\text { Regression } \\
\text { equations }\end{array}$ & Sign. F & $\begin{array}{l}\text { P-value } \\
\text { for } Y_{0}\end{array}$ \\
\hline \multicolumn{6}{|c|}{ Impact of $X_{1}$ on $Y_{1}$} \\
\hline Turkey & -0.778 & 0.605 & $724.872-8.083 \cdot \mathbf{X}_{1}$ & 0.000 & 0.000 \\
\hline Italy & -0.763 & 0.582 & $1990.885-142.363 \cdot \mathbf{X}_{1}$ & 0.000 & 0.000 \\
\hline Spain & -0.740 & 0.548 & $1300.874-113.453 \cdot \mathbf{X}_{1}$ & 0.000 & 0.000 \\
\hline Denmark & -0.706 & 0.498 & $265.547-23.471 \cdot \mathbf{X}_{1}$ & 0.000 & 0.000 \\
\hline \multicolumn{6}{|c|}{ Impact of $X_{1}$ on $Y_{2}$} \\
\hline Portugal & -0.737 & 0.543 & $9.348-0.033 \cdot \mathbf{X}_{1}$ & 0.535 & 0.000 \\
\hline Denmark & 0.707 & 0.500 & $19.414+1.669 \cdot \mathbf{X}_{1}$ & 0.000 & 0.000 \\
\hline \multicolumn{6}{|c|}{ The impact of $X_{1}$ on $Y_{3}$ - no this type of linear relationship } \\
\hline \multicolumn{6}{|c|}{ Impact of $\mathrm{X}_{2}$ on $\mathrm{Y}_{2}$} \\
\hline Australia & -0.896 & 0.803 & $26.844-0.167 \cdot \mathbf{X}_{2}$ & 0.000 & 0.000 \\
\hline Iceland & -0.760 & 0.578 & $86.270-77.309 \cdot \mathbf{X}_{2}$ & 0.000 & 0.000 \\
\hline Netherlands & -0.737 & 0.543 & $21.464-0.109 \cdot \mathbf{X}_{2}$ & 0.000 & 0.000 \\
\hline France & -0.732 & 0.536 & $16.066-0.015 \cdot \mathbf{X}_{2}$ & 0.000 & 0.000 \\
\hline Turkey & -0.723 & 0.523 & $22.660-1.176 \cdot \mathbf{X}_{2}$ & 0.000 & 0.000 \\
\hline Belgium & -0.720 & 0.518 & $10.631-0.045 \cdot \mathbf{X}_{2}$ & 0.000 & 0.000 \\
\hline \multicolumn{6}{|c|}{ Impact of $X_{2}$ on $Y_{3}$} \\
\hline Belgium & -0.865 & 0.748 & $11.752-0.088 \cdot \mathbf{X}_{2}$ & 0.000 & 0.000 \\
\hline Germany & -0.829 & 0.687 & $12.188-0.016 \cdot \mathbf{X}_{2}$ & 0.000 & 0.000 \\
\hline Italy & -0.760 & 0.578 & $13.328-0.025 \cdot \mathbf{X}_{2}$ & 0.000 & 0.000 \\
\hline Norway & 0.757 & 0.573 & $5.970+0.114 \cdot \mathbf{X}_{2}$ & 0.000 & 0.000 \\
\hline
\end{tabular}

The correlation-regression results in Table 3 indicate, that a moderate downhill linear relationship is related to almost every case of interconnection between $X_{n}$ and $Y_{n}$. Its conditions display the inversely proportional dependence $(-0.700<\mathbf{r} \leq-0.500)$ between the inflation (consumer prices), insurance (total gross insurance premiums) and economic growth (gross domestic product) and food market security (food exports - \% of merchandise exports; food import) - $\%$ of merchandise import).

Table 4 shows the number and list of countries where inflation and total gross insurance premiums have a weak uphill (downhill) linear relationship with GDP and food market security indicators (food exports and food import).

Consequently, a weak uphill (downhill) linear relationship between inflation, insurance and economic growth and food market security indicators is associated to the list of countries in Table 4. Besides, correlation-regression statistics indicate a week directly $(0.300 \leq \mathbf{r}<$ $0.500)$ and inversely $(-0.500<\mathbf{r} \leq-0.300)$ proportional dependence between $X_{n}$ and $Y_{n}$ values.

Furthermore, the research results indicate group 4, that includes list of countries where inflation $\left(\mathrm{X}_{1}\right)$ and insurance $\left(\mathrm{X}_{2}\right)$ have not linear relationship (negligible correlation) with economic growth $\left(\mathrm{Y}_{1}\right)$ and food market security $\left(\mathrm{Y}_{2}, \mathrm{Y}_{3}\right)$ and meets the following criteria: $0.000 \leq \mathbf{r}<0.300(-0.300<\mathbf{r} \leq 0.000)$. 
Table 3

List of countries where inflation $\left(X_{1}\right)$ and insurance $\left(X_{2}\right)$ have a moderate uphill (downhill) linear relationship with economic growth $\left(\mathbf{Y}_{1}\right)$ and food market security $\left(\mathbf{Y}_{2}, \mathbf{Y}_{3}\right)$

\begin{tabular}{|c|c|c|c|c|c|}
\hline Country & $\mathbf{r}$ & $\mathbf{r}^{2}$ & $\begin{array}{c}\begin{array}{c}\text { Regression } \\
\text { equations }\end{array} \\
\end{array}$ & Sign. F & $\begin{array}{c}\text { P-value } \\
\text { for } Y_{0}\end{array}$ \\
\hline \multicolumn{6}{|c|}{ Impact of $X_{1}$ on $Y_{1}$} \\
\hline France & -0.632 & 0.399 & $1910.309-157.911 \cdot \mathbf{X}_{1}$ & 0.000 & 0.000 \\
\hline Switzerland & -0.607 & 0.368 & $492.251-73.822 \cdot \mathbf{X}_{1}$ & 0.000 & 0.000 \\
\hline UK & -0.550 & 0.303 & $2641.153-252.696 \cdot \mathbf{X}_{1}$ & 0.001 & 0.000 \\
\hline Japan & -0.529 & 0.280 & $4589.123-566.657 \cdot \mathbf{X}_{1}$ & 0.001 & 0.000 \\
\hline Finland & -0.519 & 0.269 & $181.728-13.506 \cdot \mathbf{X}_{1}$ & 0.000 & 0.000 \\
\hline Portugal & -0.514 & 0.264 & $200.732-8.830 \cdot \mathbf{X}_{1}$ & 0.000 & 0.000 \\
\hline \multicolumn{6}{|c|}{ Impact of $X_{1}$ on $Y_{2}$} \\
\hline France & 0.604 & 0.365 & $13.014+0.357 \cdot \mathbf{X}_{1}$ & 0.000 & 0.000 \\
\hline Turkey & 0.559 & 0.312 & $11.337+0.140 \cdot \mathbf{X}_{1}$ & 0.000 & 0.000 \\
\hline \multicolumn{6}{|c|}{ Impact of $X_{1}$ on $Y_{3}$} \\
\hline Italy & 0.676 & 0.457 & $9.466+0.445 \cdot \mathbf{X}_{1}$ & 0.000 & 0.000 \\
\hline Ireland & -0.637 & 0.406 & $10.178-0.033 \cdot \mathbf{X}_{1}$ & 0.803 & 0.000 \\
\hline Portugal & -0.577 & 0.333 & $13.133+0.042 \cdot \mathbf{X}_{1}$ & 0.250 & 0.000 \\
\hline UK & 0.506 & 0.256 & $8.700+0.333 \cdot \mathbf{X}_{\mathbf{1}}$ & 0.002 & 0.000 \\
\hline \multicolumn{6}{|c|}{ Impact of $X_{2}$ on $Y_{2}$} \\
\hline UK & -0.674 & 0.454 & $7.488-0.004 \cdot \mathbf{X}_{2}$ & 0.000 & 0.000 \\
\hline Switzerland & 0.615 & 0.378 & $2.454+0.017 \cdot \mathbf{X}_{2}$ & 0.000 & 0.000 \\
\hline Italy & 0.608 & 0.370 & $6.337+0.009 \cdot \mathbf{X}_{2}$ & 0.000 & 0.000 \\
\hline \multicolumn{6}{|c|}{ Impact of $X_{2}$ on $Y_{3}$} \\
\hline France & -0.682 & 0.465 & $11.001-0.008 \cdot \mathbf{X}_{2}$ & 0.000 & 0.000 \\
\hline Switzerland & -0.682 & 0.465 & $7.528-0.028 \cdot \mathbf{X}_{2}$ & 0.000 & 0.000 \\
\hline UK & -0.670 & 0.449 & $10.910-0.005 \cdot \mathbf{X}_{2}$ & 0.000 & 0.000 \\
\hline Netherlands & -0.577 & 0.333 & $14.810-0.061 \cdot \mathbf{X}_{2}$ & 0.000 & 0.000 \\
\hline Spain & -0.512 & 0.262 & $12.106-0.023 \cdot \mathbf{X}_{2}$ & 0.001 & 0.000 \\
\hline
\end{tabular}

Thus, it was found that negligible correlation (not linear relationship) is associated with following interconnection between $Y_{n}$ and $X_{n}$ for research countries:

1. Interconnection between inflation or consumer prices $\left(\mathrm{X}_{1}\right)$ and gross domestic product $\left(\mathrm{Y}_{1}\right)$ in Germany, Ireland and Netherlands;

2. Interconnection between inflation or consumer prices $\left(\mathrm{X}_{1}\right)$ and food exports $\left(\mathrm{Y}_{2}\right)$ in Iceland, Japan, Norway, Belgium, Germany, Netherlands, Ireland and Spain;

3. Interconnection between inflation or consumer prices $\left(\mathrm{X}_{1}\right)$ and food import $\left(\mathrm{Y}_{3}\right)$ in Norway, Spain, Japan, Germany, Australia, Netherlands and Iceland;

4. Interconnection between insurance or total gross insurance premiums $\left(\mathrm{X}_{2}\right)$ and food exports $\left(\mathrm{Y}_{2}\right)$ in Finland, Spain, Germany and Norway;

5. Interconnection between insurance or total gross insurance premiums $\left(\mathrm{X}_{2}\right)$ and food import $\left(\mathrm{Y}_{3}\right)$ in Ireland, Iceland, Turkey and Portugal. 
Table 4

List of countries where inflation $\left(X_{1}\right)$ and insurance $\left(X_{2}\right)$ have a weak uphill (downhill) linear relationship with economic growth $\left(\mathbf{Y}_{1}\right)$ and food market security $\left(\mathbf{Y}_{2}, \mathbf{Y}_{3}\right)$

\begin{tabular}{|c|c|c|c|c|c|}
\hline Country & $\mathbf{r}$ & & $\begin{array}{c}\text { Regression } \\
\text { equations }\end{array}$ & Sign. F & $\begin{array}{l}\text { P-value } \\
\text { for } Y_{0}\end{array}$ \\
\hline \multicolumn{6}{|c|}{ Impact of $X_{1}$ on $Y_{1}$} \\
\hline Iceland & -0.475 & 0.226 & $13.234-0.203 \cdot \mathbf{X}_{1}$ & 0.000 & 0.000 \\
\hline Australia & -0.474 & 0.225 & $-39.573+16.58 \cdot \mathbf{X}_{1}$ & 0.000 & 0.000 \\
\hline Belgium & -0.400 & 0.160 & $338.361-32.52 \cdot \mathbf{X}_{1}$ & 0.000 & 0.000 \\
\hline Norway & -0.365 & 0.133 & $381.487-42.74 \cdot \mathbf{X}_{1}$ & 0.043 & 0.000 \\
\hline \multicolumn{6}{|c|}{ Impact of $X_{1}$ on $Y_{2}$} \\
\hline $\mathrm{UK}$ & 0.425 & 0.181 & $5.863+0.220 \cdot \mathbf{X}_{1}$ & 0.012 & 0.000 \\
\hline Australia & 0.399 & 0.159 & $20.381+0.963 \cdot \mathbf{X}_{1}$ & 0.001 & 0.000 \\
\hline Italy & -0.381 & 0.145 & $7.501-0.108 \cdot \mathbf{X}_{1}$ & 0.022 & 0.000 \\
\hline Switzerland & -0.362 & 0.131 & $3.325-0.116 \cdot \mathbf{X}_{1}$ & 0.030 & 0.000 \\
\hline Finland & 0.336 & 0.113 & $2.441+0.110 \cdot \mathbf{X}_{1}$ & 0.000 & 0.000 \\
\hline \multicolumn{6}{|c|}{ Impact of $X_{1}$ on $Y_{3}$} \\
\hline Denmark & -0.481 & 0.231 & $12.837-0.122 \cdot \mathbf{X}_{1}$ & 0.001 & 0.000 \\
\hline France & 0.461 & 0.213 & $10.573+0.233 \cdot \mathbf{X}_{1}$ & 0.067 & 0.000 \\
\hline Finland & -0.460 & 0.212 & $6.887+0.113 \cdot \mathbf{X}_{1}$ & 0.081 & 0.000 \\
\hline Turkey & 0.456 & 0.208 & $4.101+0.020 \cdot \mathbf{X}_{1}$ & 0.005 & 0.000 \\
\hline Switzerland & 0.416 & 0.173 & $6.035+0.205 \cdot \mathbf{X}_{1}$ & 0.012 & 0.000 \\
\hline Belgium & 0.324 & 0.105 & $9.758+0.329 \cdot \mathbf{X}_{1}$ & 0.000 & 0.000 \\
\hline \multicolumn{6}{|c|}{ Impact of $X_{2}$ on $Y_{2}$} \\
\hline Portugal & 0.445 & 0.198 & $7.727+0.156 \cdot \mathbf{X}_{2}$ & 0.001 & 0.000 \\
\hline Japan & -0.408 & 0.166 & $0.822-0.001 \cdot \mathbf{X}_{2}$ & 0.013 & 0.000 \\
\hline Ireland & 0.403 & 0.162 & $8.279+0.028 \cdot \mathbf{X}_{2}$ & 0.121 & 0.000 \\
\hline Denmark & -0.397 & 0.158 & $23.811-0.050 \cdot \mathbf{X}_{2}$ & 0.020 & 0.000 \\
\hline \multicolumn{6}{|c|}{ Impact of $X_{2}$ on $Y_{3}$} \\
\hline Australia & 0.486 & 0.236 & $4.896+0.011 \cdot \mathbf{X}_{2}$ & 0.003 & 0.000 \\
\hline Finland & 0.451 & 0.203 & $5.350+0.149 \cdot \mathbf{X}_{2}$ & 0.006 & 0.000 \\
\hline Japan & -0.435 & 0.189 & $16.925-0.012 \cdot \mathbf{X}_{2}$ & 0.008 & 0.000 \\
\hline Denmark & 0.401 & 0.226 & $12.269+0.009 \cdot \mathbf{X}_{2}$ & 0.019 & 0.000 \\
\hline
\end{tabular}

\section{Comparisons with previous studies}

The critical literature review of previous studies on interconnection and impact of insurance and inflation on economic growth and food market security shows that it is very important research direction and it still need more analysis and research. Comparing with previous studies it was found that Spörri, Baráth, Bokusheva and Fertö (2012) described the negative impact of insurance on economic indicators (economic profit, productivity of labor and productivity of land) [39]. According by Juan et al. (2016) it was proposed the model that counts several features of the insurance program based on the empirical parameter of 
interest [40]. Ul Din et al. (2017) stated that for developed countries there is a significant relationship between life insurance, net written premiums and density [41]. Additionally, Cristeaa et al. (2014) have determined that there is a high correlation between insurance penetration, density and economic growth, measured using GDP per capita [42]. However, Wang \& Li (2019) argued that development of China's foreign capital insurance market has not promoted China's economic growth [43].

The research results of the Mamo \& Lin (2012) stated that inflation is negatively and significantly related to economic growth. Inflation and real GDP per capita tend to be the opposite. Therefore, inflation can be used to forecast economic growth for all the sample countries, and economic growth can also be used to forecast inflation for the two sample countries [44]. In addition, Shirinyan and Arych (2019) have studied the Impact of the insurance costs on the competitiveness of food industry enterprises of Ukraine in the context of the food market security [45]. According by Naseri \& Zada (2013) was confirmed that there are negative links between inflation and economic growth in the context of Malaysia. But, applying the OLS method to annual data from 1970 to 2011, the study found a statistically significant positive relationship between inflation and Malaysia's economic growth [46].

\section{Conclusions}

This research study develops a new model by identifying the type of influence of inflation (consumer prices in annual \%) and insurance (total gross insurance premiums in US Dollar) on economic growth (gross domestic product in US Dollar) and food market security (two indicators: food exports in \% of merchandise exports and food import in $\%$ of merchandise import). The results indicate four groups by level of interconnection between these economic indicators as follow below.

1. A strong uphill (downhill) linear relationship that related to the following: to impact of inflation on GDP in Turkey, Italy, Spain and Denmark; to impact of inflation on food export in Portugal and Denmark; to impact of insurance on food export in Australia, Iceland, Netherlands, France, Turkey and Belgium; to impact of insurance on food import in Belgium, Germany, Italy and Norway.

2. A moderate uphill (downhill) linear relationship that related to the following: to impact of inflation on GDP in France, Switzerland, United Kingdom, Japan, Finland and Portugal; to impact of inflation on food export in France and Turkey; to impact of inflation on food import in Italy, Ireland, Portugal and United Kingdom; to impact of insurance on food export in United Kingdom, Switzerland and Italy; to impact of insurance on food import in France, Switzerland, United Kingdom, Netherlands and Spain.

3. A weak uphill (downhill) linear relationship that related to the following: to impact of inflation on GDP in Iceland, Australia, Belgium and Norway; to impact of inflation on food export in United Kingdom, Australia, Italy, Switzerland and Finland; to impact of inflation on food import in Denmark, France, Finland, Turkey, Switzerland and Belgium; to impact of insurance on food export in Portugal, Japan, Ireland and Denmark; to impact of insurance on food import in Australia, Finland, Japan and Denmark.

In addition, the fourth group include a list of all other countries in cases where between $Y_{n}$ and $X_{n}$ there is negligible correlation (not linear relationship). 


\section{References}

1. Isaboke H.N., Zhang Q., Nyarindo W.N. (2016), The effect of weather index based micro-insurance on food security status of smallholders, Agricultural and Resource Economics: International Scientific E-Journal, 2(3), Available at: www.arejournal.com.

2. Bogdan Mârzaa, Carmen Angelescub, Cristina Tindecheb (2015), Agricultural Insurances and Food Security. The New Climate Change Challenges, Procedia Economics and Finance, 27, pp. 594-599.

3. How can we make insurance work for food security? Conference Report, Agricultural Insurance Conference, Berlin.

4. Akinrinola O.O., Okunola A.M. (2014), Effects of Agricultural Insurance Scheme on Agricultural Production in Ondo State, MPRA Paper, 74558.

5. Kim Y., Pendell D.L., Yu J. (2018), Effects of Crop Insurance on Farm Disinvestment and Exit Decisions, Available at: https://arefiles.ucdavis.edu.

6. Zhao Y., Preckel P. (2016), An empirical analysis of the effect of crop insurance on farmers' income, China Agricultural Economic Review, 8(2), pp. 299-313.

7. Jisang Yua J., Sumnerb D.A. (2017), Effects of subsidized crop insurance on crop choices, Agricultural Economics, 49, pp. 533-545.

8. Bachev H. (2012), Risk Management in the Agri-food Sector, Contemporary Economics, 7(1), pp. 45-62.

9. Lorant A., Farkas M.F. (2015), Risk management in the agricultural sector with special attention to insurance, Polish Journal of Management Studies, 11(2).

10. Outreville J.F. (2011), The relationship between insurance growth and economic development: 80 empirical papers for a review of the literature, Working Paper, 12.

11. Njegomir V., \& Stojić D. (2010), Does insurance promote economic growth: the evidence from ex-Yugoslavia Region, Ekon. Misao i Praksa DBK., XIX, 1, pp. 31-48.

12. Stojaković A., \& Jeremić L. (2016), Development of the insurance sector and economic growth in countries in transition, Megatrend revija $\sim$ Megatrend Review, 13(3), pp. 83106.

13. Sawadogo et al. (2018), Life Insurance Development and Economic Growth: Evidence from Developing Countries, Journal of Economic Development, 48(2).

14. Petrova Y. (2019), On cointegration between the insurance market and economic activity, Empirical Economics, DOI: https://doi.org/10.1007/s00181-019-01669-6

15. Satrovic E. (2019), Meta-Analysis of the Relationship between Life Insurance and Economic Growth, Journal of Yasar University, 14, pp. 118-125.

16. Petrova Y. (2014), The Relationship between Insurance Market Activity and Economic Growth, LUP Student Papers.

17. Hu H., Su M., Lee W. (2013), Insurance activity and economic growth nexus in 31 regions of China: bootstrap panel causality test, Romanian Journal of Economic Forecasting, XVI(3).

18. Hui Z., \& Xin Z. (2017), The dynamic relationship between insurance development and economic growth: New evidence from China's coastal areas, African Journal of Business Management, 11(5), pp. 102-109, DOI: 10.5897/AJBM2016.8219

19. Hussein M., \& Alam S. (2019), The Role of Insurance Sector in the Development of the Economy of Oman, Global Journal of Economics and Business, 6(2), pp. 356- 364.

20. Ramoutar R.S. (2019), The Effects of Insurances, Pensions and Mutual Funds on Economic Growth, Journal of Economics and Public Finance, 6(1), pp. 17-27. 
21. Nwani A.T., \& Omankhanlen A.E. (2019). Insurance Receivables and Economic Growth: The Case of Nigeria, Journal of Physics: Conference Series, 1378, DOI: 10.1088/1742-6596/1378/4/042093

22. Pradhan R.P et al. (2017). Is there a link between economic growth and insurance and banking sector activities in the G-20 countries? Review of Financial Economics, 33, pp. $12-28$.

23. Qayyum A., Sultana B. (2018), Factors of Food Inflation: Evidence from Time Series of Pakistan, Journal of Banking and Finance Management, 1(2), pp. 23-30.

24. Islam A. (2013), Impact of inflation on import: An empirical study, International Journal of Economics, Finance and Management Sciences, 1(6), pp. 299-309, DOI: 10.11648/j.ijefm.20130106.16

25. Muktadir-Al-Mukit D., Shafiullah A.Z.M., Ahmed R. (2013), Inflation Led Import or Import Led Inflation: Evidence from Bangladesh, Asian Business Review, 2(2), pp. 7 11.

26. Kiganda E.O., Obange N., Adhiambo S. (2017), The Relationship between Exports and Inflation in Kenya: An Aggregated Econometric Analysis, Asian Journal of Economics, Business and Accounting, 3(1), pp. 1-12.

27. Ahmed R.R., Ghauri S.P., Vveinhardt J., Streimikiene D. (2018), An empirical analysis of export, import, and inflation: a case of Pakistan, Romanian Journal of Economic Forecasting, XXI(3), pp. 117-130.

28. Gazdar H., Mallah H.B. (2013), Inflation and Food Security in Pakistan: Impact and Coping Strategies, IDS Bulletin, 44(3), pp. 31-37.

29. Løvendal C.R., Jakobsen K.T. and Jacque A. (2007), Food Prices and Food Security in Trinidad and Tobago, ESA Working Paper, pp. 07-27.

30. Huppé G.A., Shaw S., Dion J., Voora V. (2013), Food Price Inflation and Food Security: A Morocco case study, Published by the International Institute for Sustainable Development.

31. Mukoka S. (2018), An Econometric Assessment of the Impact of Inflation on Economic Growth: A Case Study of Zimbabwe Economy, Economics, 7(1), pp. 17-22.

32. Švigir M., Miloš J. (2017), Relationship between inflation and economic growth; comparative experience of Italy and Austria, FIP - Financije i pravo, 5(2), pp. 91-101.

33. Ruzima M., Veerachamy P. (2016), Impact of inflation on economic growth: a survey of literature review, International Multidisciplinary Research Journal, 5(10), pp. 1-9.

34. Mishchenko V., Naumenkova S., Mishchenko S., Ivanov V. (2018), Inflation and economic growth the search for a compromise for the Central Bank's monetary policy, Banks and Bank Systems, 13(2), pp. 153-163.

35. Akinsola F.A., Odhiambo N.M. (2017), Inflation and Economic Growth:a Review of The International Literature, Comparative Economic Research, 20(3), pp. 41-56.

36. The official site of The World Bank, Available at: https://data.worldbank.org/

37. The official site of The Organisation for Economic Co-operation and Development $(O E C D)$, Available at: https://www.oecd.org/

38. Malyovanyi M., Nepochatenko O., \& Nesterchuk Y. (2018). Conceptual Approaches to Improving the Functioning of Non-state Social Insurance Institutions in Ukraine. Economics \& Sociology, 11(2), pp. 289-304.

39. Spörri et al. (2012), The Impact of Crop Insurance on the Economic Performance of Hungarian Cropping Farms, EAAE Seminar "Price Volatility and Farm Income Stabilisation", 123, Dublin. 
40. Juan H. et al. (2016), Estimating the Effect of Crop Insurance on Input Use When Insured Farmers are Monitored, Agricultural \& Applied Economics Association Annual Meeting, Boston, Massachusetts.

41. Ul Din et al. (2017), Does insurance promote economic growth: A comparative study of developed and emerging/developing economies, Cogent Economics \& Finance, 5.

42. Cristeaa et al. (2014), The relationship between insurance and economic growth in Romania compared to the main results in Europe - a theoretical and empirical analysis, Procedia Economics and Finance, 8, pp. 226-235.

43. Wang D.S., \& Li Y.M. (2019), The Development of Foreign Capital Insurance Market, FDI and Economic Growth in China. Modern Economy, 10, pp. 872-885. doi: https://doi.org/10.4236/me.2019.103058.

44. Mamo F., Lin X. (2012), Economic growth and inflation: A panel data analysis, Södertörns University, Department of Social Sciences.

45. Shirinyan L., Arych M. (2019), Impact of the insurance costs on the competitiveness of food industry enterprises of Ukraine in the context of the food market security, Ukrainian Food Journal, 2019, 8(2), pp. 368-385.

46. Naseri M., Zada N. (2013), Effect of Inflation on Economic Growth; Evidence from Malaysia, Available at: https://www.researchgate.net/publication/ 327034375_Effect_of_Inflation_on_Economic_Growth_Evidence_from_Malaysia. 